МАШИН03НАВСТВO

УДК 621.865.8(031)

DOI https://doi.org/10.32838/2663-5941/2020.4/01

\title{
Поліщук М.М.
}

Національний технічний університет України

«Київський політехнічний інститут імені Ігоря Сікорського»

\section{Ткач M.М.}

Національний технічний університет України

«Київський політехнічний інститут імені Ігоря Сікорського»

\section{ДОСЛІДЖЕННЯ МОДУЛЯ АЕРОДИНАМІЧНОЇ ПІДНІМАЛЬНОЇ СИЛИ МОБІЛЬНОГО РОБОТА ДОВІЛЬНОЇ ОРІЄНТАЦЇ̈}

Мобільні роботи вертикального переміщення, відомі в закордонних публікаціях під назвою Сlimbеr Robot (альпіністський робот), є порівняно новим засобом мобільної робототехніки, здатним виконувати виробничі завдання на поверхнях довільної орієнтачії в технологічному просторі. Такі роботи призначені для виконання різноманітних операцій в екстремальних умовах виробництва, в тому числі й техногенних катастроф, при одночасному подоланні гравітаційного навантаження. Закордонні експериментальні дослідження зазначених роботів присвячені переважно створенню підсистем зчеплення робота $з$ поверхнею переміщення, які є невід'ємною частиною мобільних роботів довільної орієнтачії в просторі.

Дані дослідження містять результати експериментальної апробаиії принципово нового підходу протидї гравітаційному навантаженню мобільного робота, а саме доиільності оснащення робота джерелом реактивної тяги нехімічного походження. Як таке джерело запропонований пневматичний генератор аеродинамічної піднімальної сили, щьо частково компенсує або повністю долає гравітаиійне навантаження, не допускаючи при изьоу перетворення мобільного робота на літальний апарат, щоб забезпечити виконання контактних силових технологічних операчій у прочесі обслуговування різних промислових об'єктів. Інакше кажучи, сила реактивної тяги не має перевищувати сил зчеплення мобільного робота з поверхнею переміщення. Крім того, запропонована стаття містить експериментальне розв'язання задачі знаходження квазіоптимальних значень аеродинамічної піднімальної сили залежно від параметрів генератора реактивної тяги. Наведені методика й опис постановки повнофакторного експерименту з варіюванням незалежних факторів на двох екстремальних рівнях. Зрештою, застосування аеродинамічної піднімальної сили як засобу протидії гравітаційному навантаженню сприяс підвищенню надійності утримання мобільних роботів на поверхні переміщення довільної орієнтації в технологічному просторі.

Ключові слова: мобільні роботи, крокуючі механізми, роботи вертикального переміщення, аеродинамічна сила.

Постановка проблеми. Для дослідження режимів роботи модуля аеродинамічної піднімальної сили мобільного робота необхідна постановка екстремального повнофакторного експерименту (ПФЕ), який дасть змогу не тільки апробувати доцільність застосування пневматичної реактивної тяги для мобільних роботів, але й здійснити пошук оптимальних або, коректніше буде помітити, квазіоптимальних значень факторів, що визначають ефективність роботи пневматичного генератора тяги. У зв'язку з відсутністю подібних досліджень у цій галузі спочатку сформульоване завдання постановки ПФЕ далі описана методика експерименту й виконані дисперсійний і регресійний аналізи отриманих експериментальних даних, включаючи перевірку отриманої регресійної моделі на адекватність реальному процесу. Виконане дослідження регресійної та аналітичної моделей генератора аеродинамічної піднімальної сили для мобільних роботів довільної орієнтації в просторі.

Аналіз останніх досліджень i публікацій. Як зазначено вище, майже всі дослідження в галузі створення мобільних роботів довільної орієнтації 
присвячені вдосконаленню пристроїв зчеплення робота з поверхнею переміщення. Така спрямованість виправдана тим, що підсистеми зчеплення $\epsilon$ визначальним чинником утримання мобільного робота на поверхні переміщення в технологічному просторі. Так, наприклад, в роботі “A Survey of Technologies and Applications for Climbing Robots Locomotion and Adhesion" [1, c. 4-11] запропоновані різноманітні засоби зчеплення мобільних роботів із поверхнею переміщення, що долають гравітаційне навантаження для гарантованого втримання робота на довільно орієнтованій поверхні переміщення. Наведені технічні рішення передбачають застосування вакуумних, електромагнітних, механічних захватів, а також засобів на основі адгезії, але без прикладів застосування аеродинамічної піднімальної сили.

Система утримання робота на поверхні переміщення як генератора вакууму запропонована в конструкції робота CCNY Robotics Lab City University New York, що відображена в дослідженнях [2, с. 35]. Автономним генератором вакууму створюється зона пониженого тиску між корпусом робота і поверхнею переміщення, завдяки чому робот і утримується на вказаній поверхні. Відзнакою мобільного робота «Boston Dynamics» $\epsilon$ наявність пласко паралельних педіпуляторів, оснащених голчастими механічними захватами $[3$, c. 2], що дають змогу роботу долати гравітаційне навантаження при переміщенні як на поверхнях стін висотних будинків, так і по поверхні стовбурів дерев. Віддаючи належне оригінальності конструкцій наведених моделей, варто зауважити, що роботи з механічним зчепленням [4, с. 25-27] відрізняються підвищеною надійністю, але варто зауважити, що цей вид зчеплення як засіб протидії гравітаційному навантаженню не $\epsilon$ інваріантним до різних поверхонь переміщення довільної орієнтації.

Дослідження, присвячені моделюванню динаміки переміщень мобільних роботів [5], спрямовані на зменшення динамічних навантажень, що також сприяє підвищенню надійності утримання мобільного робота на поверхні руху. 3 цієї точки зору становить інтерес методологічний підхід до моделювання умов зчеплення мобільного робота 3 поверхнею довільної орієнтації, запропонований у роботі [6, с. 14-18]. Метод заснований на теорії опору матеріалів і передбачає обчислення значень нормальної напруги в зоні контакту, що порівнюється із граничним значенням напруги при розтяганні й стиску поверхні контакту. Ця модель дає змогу контролювати міцність зчеплення ніг робота $з$ поверхнею переміщення, однак у ній не відображені розв'язки, спрямовані саме на протидію гравітаційному навантаженню на мобільного робота, на відміну від такого засобу, як пневматичний генератор реактивної тяги, що запропонований у роботі «Антигравітаційний мобільний робот Поліщука» [7].

Однак у жодній із розглянутих вище публікацій не проведені експериментальні дослідження щодо застосування реактивної тяги як засобу протидії гравітаційному навантаженню, що для мобільних роботів має принципове значення. Таким чином, задача експериментальної апробації застосування генератора аеродинамічної піднімальної сили для мобільних роботів довільної орієнтації $\epsilon$ актуальною.

Постановка завдання. Експериментальна оптимізація параметрів будь-якої технічної системи, в тому числі й такої, як мобільний робот, передбачає наявність конкретного виду математичної моделі цільової функції, що зв'язує критерій оптимізації 3 керованими факторами досліджуваної системи чи процесу. Стосовно генератора тяги мобільного робота необхідно спочатку встановити вказаний критерій, яким може бути прийнята аеродинамічна піднімальна сила (реактивна тяга), спрямована на компенсацію гравітаційного навантаження 3 метою підвищення надійності втримання мобільного робота на поверхні довільної орієнтації, а потім, застосовуючи статистичні методи дослідження, встановити зв'язок між критерієм оптимізації - реактивною тягою пневматичного генератора, і незалежними змінними - детермінованими величинами (факторами), яким надають у кожній новій серії дослідів екстремальні значення. Саме тому необхідна постановка повнофакторного експерименту, що передбачає одержання, якщо не оптимальних, то, принаймні, квазіоптимальних значень параметрів генератора тяги для мобільного робота.

Виклад основного матеріалу дослідження. Результати кінематичного й динамічного аналізу мобільного робота із пневматичним генератором реактивної тяги $[8$, с. 4-8] дали змогу здійснити апріорний аналіз впливу параметрів пневматичного генератора реактивної тяги на аеродинамічну піднімальну силу. Отримані у вказаній роботі аналітичні залежності між реактивною тягою й параметрами генератора $\epsilon$ основою керування процесом протидії гравітаційному навантаженню на мобільного робота. Однак зазначені залежності не враховують стохастичного впливу параметрів генератора тяги на величину реактивної 
тяги, а головне, як і будь-яка аналітична модель, не можуть служити експериментальною апробацією застосування генератора реактивної тяги для мобільних роботів.

Як відомо, при постановці факторних експериментів функцією відгуку служить неповний квадратичний поліном, який для трьох факторів має вигляд [9, с. 113]:

$$
y=b_{0}+\sum_{i=1}^{3} b_{i} x_{i}+\sum_{i, j}^{3} b_{i j} x_{i} x_{j}+b_{1,2,3} x_{1} x_{2} x_{3}
$$

Число дослідів дорівнює $N=n^{k} m$, де $n-$ число рівнів варіювання факторів, $\kappa$ - число факторів, $m$ - кількість повторних реалізацій кожного досліду, виконувана з метою гарної відтворюваності результату досліду й зменшення дисперсій помилок вимірів. Таким чином, у нашому випадку необхідно провести $N=2^{3} 8=64$ досліди.

Крім того, при постановці факторних експериментів необхідно знати, до якого класу формул належить цільова функція. У монографії «Теория инженерного эксперимента» [11] зазначається, що більшість процесів може бути описана двома класами формул. До першого належать формули, в яких залежна змінна $\epsilon$ сумою функцій незалежних змінних, а загальне співвідношення другого класу, що допускає застосування факторних експериментів, являє собою добуток окремих функцій незалежних змінних. Причому залежності другого класу можуть бути наведені до першого за допомогою логарифмування як одного з методів лінеаризації функцій. Таким чином, завдання планованого експерименту зводиться до наведеного нижче:

1) застосуванням регресійного аналізу статистичних даних ПФЕ одержати конкретний вид експериментальної моделі функції відгуку, що пов'язує критерій оптимізації (реактивну тягу) 3 параметрами керування аеродинамічною піднімальною силою мобільного робота;

2) визначити, принаймні, квазістатичні значення параметрів генератора тяги, що зумовлюють максимум цільової функції, або, за термінологією ПФЕ, функції відгуку у факторному просторі.

Найбільш прийнятним науковим інструментом розв'язання вказаної задачі $\epsilon$ постановка екстремального ПФЕ, що належить до класу активних експериментів. Цей вид експериментів дає змогу (на відміну від пасивних) за допомогою варіювання факторів на екстремальних рівнях їхніх значень (min, max) цілеспрямовано впливати на параметр оптимізації, а також завдяки одночасній зміні факторів враховувати їх взаємодію.
Методика експериментальних досліджень, обладнання та техніка вимірювань. Відповідно до поставленої вище задачі, експериментальні дослідження керування процесом створення пневматичної реактивної тяги мобільного робота виконані за такою методикою:

- постановлено повнофакторний експеримент (ПФЕ), у процесі якого здійснювалося варіювання кожного 3 параметрів генератора тяги на двох екстремальних рівнях (min, max) 3 одночасною реєстрацією величин пневматичної реактивної тяги;

- побудована регресійна модель функції відгуку параметра оптимізації й статистична перевірка адекватності отриманої моделі реальному процесу керування генератором тяги;

- визначено напрями пошуку області оптимуму на основі порівняльного аналізу аналітичного й емпіричного моделювання керування процесом створення пневматичної аеродинамічної піднімальної сили мобільного робота;

- виконано чисельний аналіз функції відгуку й визначення координат умовного екстремуму цільової функції.

Для проведення досліджень був створений експериментальний стенд, принципова схема якого показана на рис. 1, а загальний вид на рис. 2 . Стенд включає джерело підвищеного тиску (до 8 бар) стисненого повітря у вигляді компресора 1 , який через блок підготовки повітря 2 (що включає фільтр, вологопоглинач і регулятор тиску), манометр 3 і пневматичний розподільник 4 створює в камері «А» генератора тяги 5 підвищений тиск, контроль якого здійснюється манометром 6. Стиснене повітря, проходячи через множину сопів 9, створює реактивну тягу, внаслідок чого генератор тяги 5 переміщається в напрямних поступальної кінематичної пари 7, встановленої на нерухливій основі 8. Сила створюваної реактивної тяги вимірялася цифровим динамометром 10.

Створення зовнішнього силового навантаження на генератор тяги 5 здійснювалося безштоковим пневматичним циліндром 11, встановленим на кронштейні 12. Подача стисненого повітря в силовий циліндр відбувалася за допомогою електромагнітного пневматичного розподільника 13 , керованого контролером 14. На рис. 2 показаний загальний вид експериментального стенда із пневматичним генератором тяги для мобільного робота. Як видно на фото, джерелом надлишкового тиску в камері генератора тяги 1 служив безолійний поршневий компресор 2 мод. Gentilin CS 240/24 (Італія), що створює тиск до 8 бар, із продуктивністю подачі 


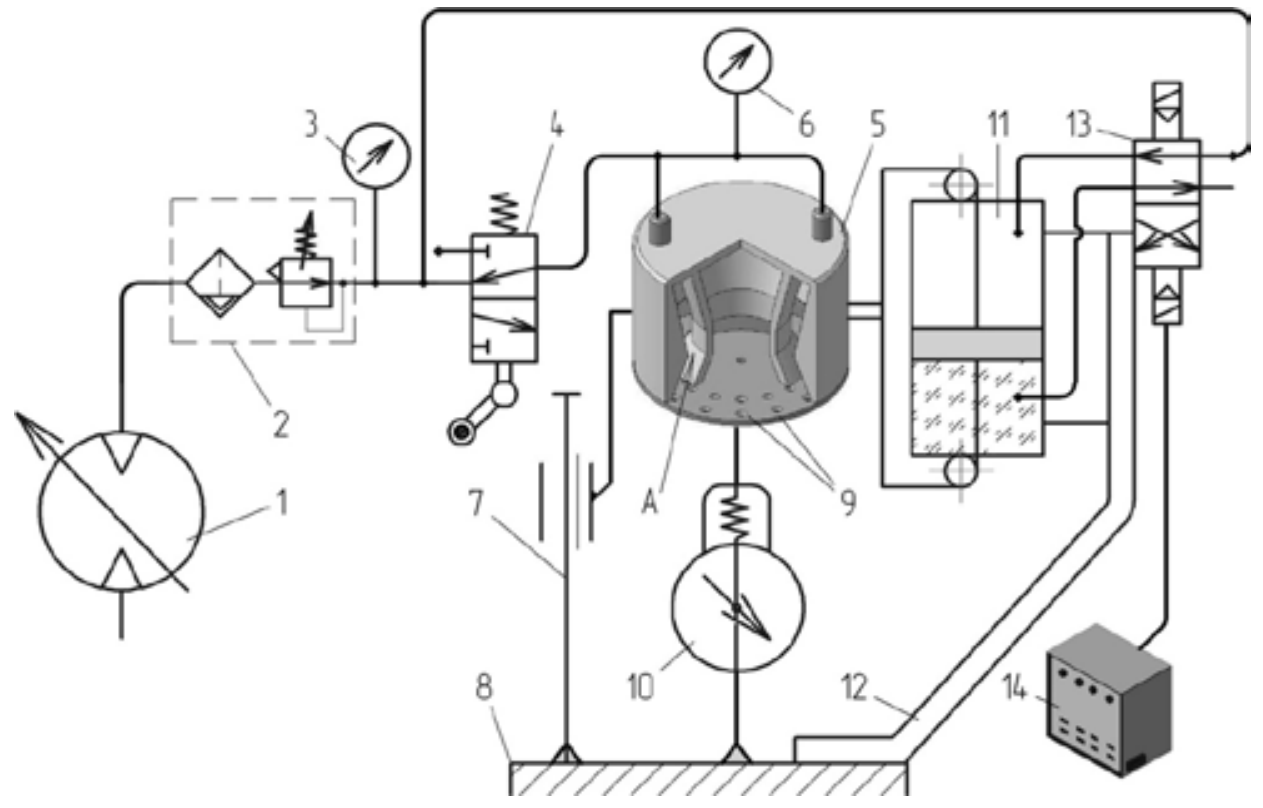

Рис. 1. Принципова схема експериментального стенда

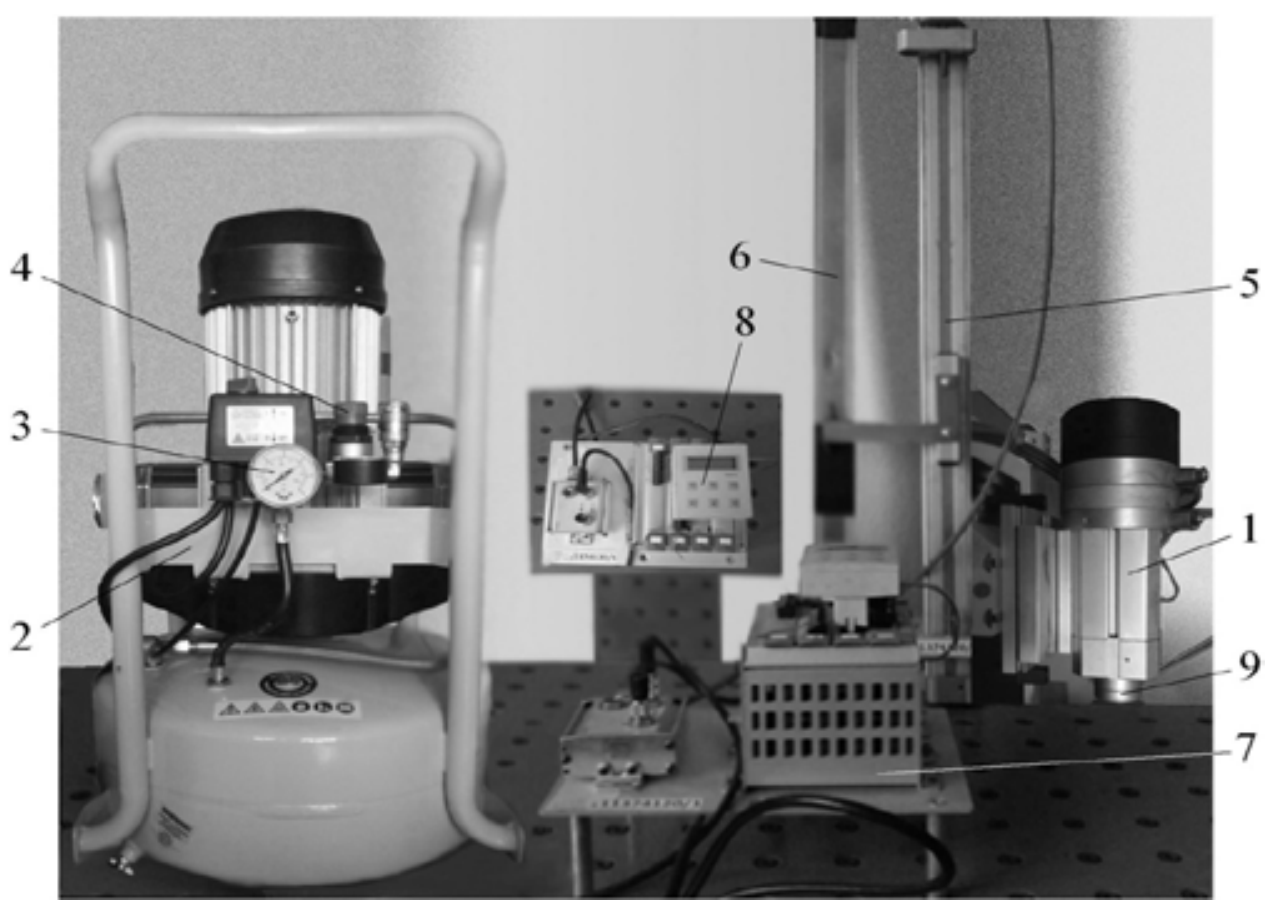

Рис. 2. Експериментальний стенд генератора тяги

стисненого повітря 150 л/хв. Контроль тиску здійснювався манометром 3, а величина тиску задавалася регулятором тиску 4 у діапазоні (2..8) бар.

Зовнішне навантаження на генератор тяги здійснювалося безштоковим пневматичним циліндром 5 мод. DNT-40-400-PPV, з'єднаним 3 аналоговим датчиком переміщення 6 і керованим контролером позиціонування 7 мод. SPC200 виробництва компанії FESTO 3 модулем інтерфейсу мод. SPC200-SCU-AIF і панеллю керування 8 мод. SРС200-MMI.

Вимір сили пневматичної тяги здійснювався цифровим динамометром 9 мод. Weiheng WH-A08 із зусиллям до 50 кг $(490 \mathrm{H})$, що має погрішність виміру \pm 5 (г) при зусиллі 0-10 (кг) та \pm 10 (г) у діапазоні зусиль 10-45 (кг). 
Власне процес створення аеродинамічної піднімальної сили генератором тяги відтворювався при варіюванні таких факторів (незалежних змінних): $F$ - ефективної площі сопів за допомогою зміни числа $n$ отворів сопів і їх діаметрів $d$ при регулюванні тиску $p$ у генераторі тяги й силового навантаження $Q$ на екстремальних рівнях згідно з матрицею планування експерименту, як це показане нижче.

У процесі експерименту від компресора (фото рис. 2) стисле повітря подавалось у генератор тяги 1 (рис. 3), встановлений на кільцях 2 Карданового підвісу, через штуцери 3 . У результаті в камері «А» створювалась зона підвищеного тиску в діапазоні 2-8 бар. Стисле повітря, стікаючи через сопла 4 мембран 5, утворювало реактивну тягу. Оскільки умови проведення повнофакторного експерименту передбачають варіювання факторів на екстремальних рівнях, вказані мембрани змінювались (із різним тиском) відповідно до значень діаметрів сопел $d_{\min }^{\max }$ та їх кількості $n_{\min }^{\max }$, включаючи основний (середній) рівень значень $d_{s}, n_{s}$ матриці планування експерименту.

Як гіпотезу, що вимагає надалі підтвердження, на етапі постановки завдання представимо цільову функцію у вигляді добутку

$$
R=C_{0} f_{1}(n) f_{2}\left(p_{j}\right) f_{3}\left(d_{k}\right) \rightarrow \max ,
$$

при обмеженнях:

$$
\begin{aligned}
& \frac{\pi d^{2}}{4} n_{\text {min }} \leq F_{i}(d, n) \leq\left(\frac{\pi d^{2}}{4} n_{\max }\right) \\
& p_{\text {min }}<p_{j} \leq p_{\text {max }} \\
& d_{\text {min }} \leq d_{k} \leq d_{\text {max }}
\end{aligned}
$$

де $R$ - аеродинамічна реактивна тяга, $\mathrm{H}$; $C_{0}-$ постійний коефіцієнт, що враховує вплив зовнішніх факторів, не відображених у цільовій функції; $f_{1}\left(n_{i}\right), f_{2}\left(p_{j}\right), f_{3}\left(d_{k}\right)$ - факторні залежності (функції змінних), що підлягають визначенню; $F$ - площа поперечного перерізу сопла, зумовлена діаметром $d($ м) отворів витікання газу і їх кількістю $n ; p_{j}$ - тиск у соплах генератора тяги, бар.

Перше із зазначених обмежень (2) змінних функції (1) вказує, що кількість сопів для витікання газу варіюється від одного до кількох, становлячи площу їх поперечного перерізу достатньою для створення реактивної піднімальної сили. Друге обмеження продиктоване тим, що міжнародний стандарт для сучасних пневматичних систем передбачає їх роботу в діапазоні тисків $p_{i}=(1 \ldots 10) \cdot 10^{5}$ Па. Третє обмеження визначає

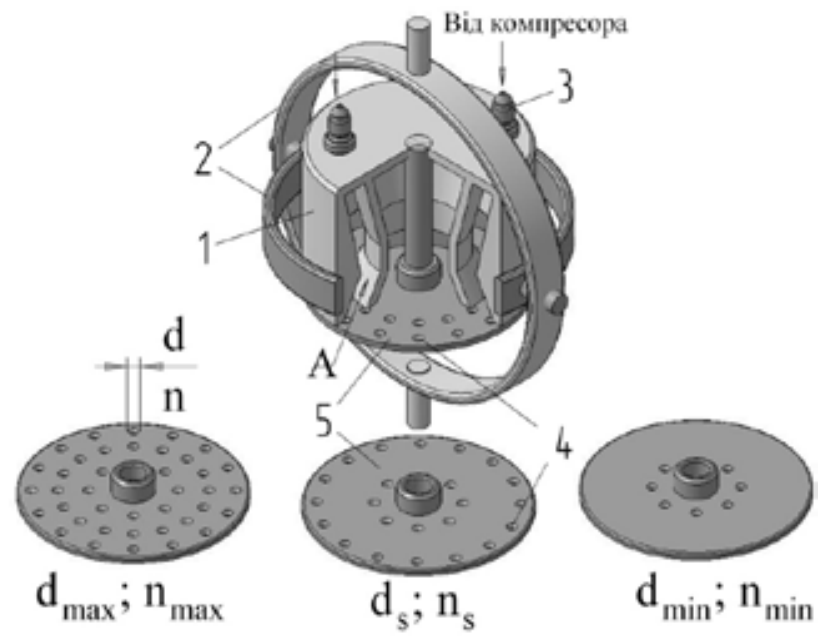

Рис. 3. Пневматичний модуль аеродинамічної сили зі змінними мембранами

необхідний і достатній діапазон зміни діаметру $d$ отворів витікання газу в генераторі тиску.

Відповідно до прийнятих обмежень (2) при постановці повнофакторного експерименту варіювання факторів цільової функції проводилося в таких межах:

$$
\begin{aligned}
& 10 \leq n_{i} \leq 80 \\
& \left(1 \leq p_{j} \leq 8\right) \cdot 10^{5} \Pi a ; \\
& \left(0,001 \leq d_{k} \leq 0,0045\right)_{\mathcal{M}},
\end{aligned}
$$

де $n_{i}-$ кількість сопів; $p_{j}$ - тиск у соплах діаметром $d_{k}$.

Загалом було проведено $N=n^{k} m=2^{3} 8=64$ досліди, де $n$ - число рівнів варіювання факторів $(\max , \min ), \kappa$ - число факторів, $m$ - кількість повторних реалізацій кожного досліду, виконуване 3 метою гарної відтворюваності результату досліду й зменшення дисперсій помилок вимірів.

При постановці факторних експериментів використовують кодовані значення змінних. Це в значній мірі полегшує не тільки обчислення постійних коефіцієнтів, але й дослідження одержуваної згодом регресійної моделі функції відгуку. Тому перейдемо від системи координат змінних $n, p, d$ у натуральному вимірі (3) до безрозмірної системи координат $x_{1}, x_{2}, x_{3}$. Використовуючи формулу [9, с. 117], перетворимо незалежні змінні на безрозмірні змінні:

$$
x_{i}=\frac{2\left(\ln \widetilde{x}_{i}-\ln \widetilde{x}_{i \max }\right)}{\ln \widetilde{x}_{i \max }-\ln \widetilde{x}_{i \text { min }}}+1,
$$

де $\tilde{x}_{i}$ - натуральний вимір змінних. Причому в безрозмірній системі координат для моделі ПФЕ типу $n^{k}=2^{3}$ верхній рівень відповідає значенню 
фактора $+1(\max )$, нижній рівень $-1(\min )$, а координати центру плану експерименту рівні й збігаються з початком системи координат.

Результати кодування верхнього й нижнього рівнів варіювання факторів зведені в табл. 1 .

Таблиця 1

\section{Рівні зміни факторів}

\begin{tabular}{|l|c|c|c|c|c|c|}
\hline \multirow{2}{*}{$\begin{array}{l}\text { Рівні } \\
\text { факторів }\end{array}$} & \multicolumn{2}{|c|}{$n$} & \multicolumn{2}{c|}{$p$, bar } & \multicolumn{2}{c|}{$d, \mathrm{м}$} \\
\cline { 2 - 7 } & $\widetilde{x}_{1}$ & $\ln \widetilde{x}_{1}$ & $\widetilde{x}_{2}$ & $\ln \tilde{x}_{2}$ & $\widetilde{x}_{3}$ & $\ln \tilde{x}_{3}$ \\
\hline Верхній +1 & 80 & 4,38 & 8 & 2,08 & 0,0045 & $-5,40$ \\
Основний 0 & 45 & - & 4,5 & - & 0,00275 & - \\
Нижній -1 & 10 & 2,3 & 2 & 0,69 & 0,001 & $-6,91$ \\
\hline
\end{tabular}

За цією таблицею знаходимо вирази для безрозмірних змінних:

$$
\begin{aligned}
& x_{1}=\frac{2\left(\ln \widetilde{x_{1}}-4,38\right)}{4,38-2,3}+1=0,95 \ln \widetilde{x_{1}}-3,19 ; \\
& x_{2}=\frac{2\left(\ln \widetilde{x_{2}}-2,08\right)}{2,08-0,69}+1=1,44 \ln \widetilde{x_{2}}-1,99 ; \\
& x_{3}=\frac{2\left(\ln \widetilde{x_{2}}+5,40\right)}{-5,40+6,91}+1=1,32 \ln \widetilde{x_{3}}+8,15 .
\end{aligned}
$$

Як зазначено вище, модель ПФЕ типу $n^{k}=2^{3}$ представляють у вигляді неповного квадратичного полінома, який запишемо з урахуванням взаємодії факторів і в кодованих змінних

$$
\begin{aligned}
y= & b_{0}+b_{1} x_{1}+b_{2} x_{2}+b_{3} x_{3}+b_{12} x_{1} x_{2}+ \\
& +b_{13} x_{1} x_{3}+b_{23} x_{2} x_{3}+b_{123} x_{1} x_{2} x_{3}
\end{aligned}
$$

У табл. 2 показані рівні варіювання незалежних факторів та їх взаємодії, тобто наведена матриця планування ПФЕ, відповідно до якої виконувалося варіювання кожного 3 факторів: $n$ - кількості отворів сопів, $p$ - тиску в соплах діаметром $d$ на двох екстремальних рівнях +1 (max) i -1 (min).

У табл. 3 наведені результати експериментальних досліджень впливу параметрів пневматичного генератора на величину реактивної тяги $R$. Вертикальні стовпці відображають отримане значення реактивної тяги, відповідне до рівнів варіювання факторів, а горизонтальні рядки містять результати відтворення кожного досліду. У стовпці $\overline{R_{i}}$ наведені усереднені значення реактивної тяги, а в табл. 4 наведені їх кодовані значення (логарифми) та дисперсії результатів дослідів.

Отримані дані дають змогу визначити чисельні значення постійних коефіцієнтів у рівнянні (6). Завдяки тому, що ПФЕ належить до ортогональних планів, значно спрощується обчислення коефіцієнтів регресії. Згідно із вказівками [9, с. 113] вони можуть бути визначені як:

$$
b_{i}=\frac{\sum_{i=1}^{n} x_{i} \bar{y}_{i}}{m},
$$

\begin{tabular}{|c|c|c|c|c|c|c|c|}
\hline \multirow{3}{*}{$\begin{array}{c}\text { №oo } \\
\text { точок } \\
\text { плану }\end{array}$} & \multicolumn{7}{|c|}{ Фактори та рівні їх варіювання } \\
\hline & \multirow{2}{*}{$\frac{x_{0}}{\text { Код }}$} & \multicolumn{2}{|c|}{$x_{1}$} & \multicolumn{2}{|c|}{$x_{2}$} & \multicolumn{2}{|c|}{$x_{3}$} \\
\hline & & Код & $n_{i}$ & Код & $p_{i}$, bar & Код & $d_{i}, \mathrm{M}$ \\
\hline 1 & + & + & 80 & + & 8 & + & 0,0045 \\
\hline 2 & + & - & 10 & + & 8 & + & 0,0045 \\
\hline 3 & + & + & 80 & - & 2 & + & 0,0045 \\
\hline 4 & + & - & 10 & - & 2 & + & 0,0045 \\
\hline 5 & + & + & 80 & + & 8 & - & 0,001 \\
\hline 6 & + & - & 10 & + & 8 & - & 0,001 \\
\hline 7 & + & + & 80 & - & 2 & - & 0,001 \\
\hline 8 & + & - & 10 & - & 2 & - & 0,001 \\
\hline \multicolumn{8}{|c|}{ Варіювання взаємодії факторів відповідно до точок плану } \\
\hline \multicolumn{2}{|c|}{$x_{1} x_{2}$} & \multicolumn{2}{|c|}{$x_{1} x_{3}$} & \multicolumn{2}{|c|}{\begin{tabular}{l|l}
$x_{2} x_{3}$ & \\
\end{tabular}} & \multicolumn{2}{|c|}{$x_{1} x_{2} x_{3}$} \\
\hline \multicolumn{8}{|c|}{ Kod } \\
\hline \multicolumn{2}{|c|}{+} & \multicolumn{2}{|c|}{+} & \multicolumn{2}{|l|}{+} & \multicolumn{2}{|c|}{+} \\
\hline \multicolumn{2}{|c|}{-} & & & + & & & \\
\hline & & & & - & & & \\
\hline & & & & - & & & \\
\hline & & & & - & & & \\
\hline & & & & - & & & \\
\hline & & & & + & & & \\
\hline & & & & + & & & \\
\hline
\end{tabular}

де $i$ - номер досліду, $m$ - число досліджених точок у плані, $\bar{y}_{i}-$ середній відгук по числу повторних дослідів у відповідній точці матриці плану ПФЕ.

Таблиця 2

Матриця планування ПФЕ 
Таблиця 3

Результати експерименту

\begin{tabular}{|c|c|c|c|c|c|c|c|c|c|}
\hline \multirow{2}{*}{$\begin{array}{c}\text { №№ } \\
\text { точок } \\
\text { плану }\end{array}$} & \multicolumn{8}{|c|}{ Реактивна тяга $R$ (при реалізації дослідів $m \rightarrow R_{1} \ldots R_{8}$ ) } & \multirow{2}{*}{$\begin{array}{c}\text { Середнє } \\
\text { значення } \\
\bar{R}_{i}\end{array}$} \\
\hline & $R_{1}$ & $R_{2}$ & $R_{3}$ & $R_{4}$ & $R_{5}$ & $R_{6}$ & $R_{7}$ & $R_{8}$ & \\
\hline 1 & 828 & 745 & 806 & 780 & 760 & 802 & 805 & 820 & 793 \\
\hline 2 & 104 & 93 & 98 & 102 & 96 & 103 & 98 & 97 & 99 \\
\hline 3 & 216 & 210 & 209 & 212 & 196 & 215 & 212 & 198 & 209 \\
\hline 4 & 27 & 25 & 26 & 24 & 28 & 24 & 26 & 25 & 26 \\
\hline 5 & 184 & 178 & 172 & 176 & 180 & 182 & 180 & 178 & 179 \\
\hline 6 & 23 & 21 & 23 & 24 & 22 & 23 & 20 & 23 & 22 \\
\hline 7 & 48 & 44 & 45 & 47 & 46 & 47 & 45 & 46 & 46 \\
\hline 8 & 6 & 5,8 & 5,5 & 6 & 5,4 & 6 & 6 & 5,6 & 5,8 \\
\hline
\end{tabular}

При $i=0$ ведеться обчислення коефіцієнта $b_{0}$. При варіюванні кожного фактора на двох рівнях $(+1)$ i $(-1)$ обчислення зводяться до приписування стовпцю $y_{i}$ знаків $(+,-)$ стовпця відповідного фактора й алгебраїчного додавання отриманих значень.

Кодовані значення та дисперсії результатів дослідів

\begin{tabular}{|c|c|c|c|}
\hline \multirow{2}{*}{$\begin{array}{c}\text { №№ } \\
\text { точок } \\
\text { плану }\end{array}$} & \multicolumn{2}{|c|}{$\begin{array}{c}\text { Кодовані значення } \\
\text { реактивної тяги } \bar{R}_{i}\end{array}$} & Дисперсії \\
\cline { 2 - 4 } & $\bar{y}_{i}=\ln \bar{R}_{i}$ & $\hat{y}_{i}$ & $\left.\widehat{\left(y_{i}\right.}-\bar{y}_{i}\right)^{2}$ \\
\hline 1 & 6,68 & 6,68 & 0,00 \\
2 & 4,59 & 4,60 & 0,0001 \\
3 & 5,34 & 5,34 & 0,00 \\
4 & 3,26 & 3,26 & 0,00 \\
5 & 5,19 & 5,18 & 0,0001 \\
6 & 3,09 & 3,10 & 0,0001 \\
7 & 3,83 & 3,84 & 0,0001 \\
8 & 1,76 & 1,76 & 0,00 \\
\hline \multicolumn{3}{|c|}{$\left.\widehat{n}^{n} \widehat{(y}_{i}-\bar{y}_{i}\right)^{2}$} & 0,0004 \\
\hline
\end{tabular}

Наступне ділення отриманого результату на число досліджених точок $(n=8)$ у плані дає шуканий коефіцієнт:

$$
\begin{gathered}
b_{0}=4,22 ; \quad b_{1}=1,04 ; \quad b_{2}=0,67 ; \quad b_{3}=0,75 ; \\
b_{12}=0,005 ; \quad b_{13}=0 ; \quad b_{23}=-0,0025 ; \\
b_{123}=-0,0025 .
\end{gathered}
$$

Обчисливши таким чином значення коефіцієнтів і підставивши їх у рівняння (6), одержимо рівняння регресії:

$$
\begin{gathered}
y=4,22+1,04 x_{1}+0,67 x_{2}+0,75 x_{3}+ \\
+0,005 x_{1} x_{2}-0,0025 x_{2} x_{3}-0,0025 x_{1} x_{2} x_{3}
\end{gathered}
$$

Перш ніж використовувати це рівняння як регресійну модель функції відгуку, його, за методикою ПФЕ, необхідно піддати статистичній перевірці, зміст якої викладено нижче.

Статистичний аналіз результатів експерименту. Згідно $з$ вимогами регресійного аналізу необхідно виконати перевірку однорідності дисперсій експериментальних даних табл. 3. Оскільки теоретичні значення дисперсій невідомі, перевірку їх однорідності здійснено на підставі статистичних оцінок отриманого емпіричного матеріалу, для чого визначалась дисперсія і-го досліду за формулою [9, с. 120]:

$$
S_{i}^{2}=\frac{1}{m-1} \sum_{k=1}^{m}\left(y_{i k}-\bar{y}_{i}\right)^{2}, \quad \mathrm{i}=\overline{1, n} ; \quad \mathrm{k}=\overline{1, m},
$$

За результатами розрахунків за формулою (9), які тут для стислості викладення опускаємо, визначено: максимальне значення дисперсій $S_{i}^{2}=0,0039$; сума всіх дисперсій $\sum_{i=1}^{n} S_{i}^{2}=0,0147$ та дисперсія відтворення $S_{m, n}^{2}=\frac{1}{n} \sum_{i=1}^{n} S_{i}^{2}=0,0018$.

Однорідність дисперсій перевіряємо за критерієм Кочрена як відношення максимальної порядкової дисперсії до суми всіх дисперсій:

$$
G=\frac{S_{\max }^{2}}{\sum_{i=1}^{n} S_{i}^{2}}=\frac{0,0039}{0,0147}=0,2653,
$$

Прийнявши рівень значимості (звичайно $q=0,05)$ і визначивши числа ступенів свободи: $f_{1}=m-1=7 ; f_{2}=n=8$, за таблицею [10] додатка знаходимо критичне відношення $G_{\kappa p}=0,4137$ i порівнюємо його 3 розрахунковим $G=0,2653<G_{k p}=0,4137$. Результат цього порівняння дає змогу прийняти гіпотезу про однорідність дисперсій, що своєю чергою дає змогу 
використати емпіричний матеріал табл. 3 для одержання апроксимуючої моделі функції відгуку.

Перевірку значимості коефіцієнтів рівняння регресії (8) здійснимо за допомогою $\mathrm{t}$ - критерію Стьюдента. Для цього знаходимо дисперсію помилки визначення коефіцієнтів:

$$
\begin{gathered}
S_{b_{1}}^{2}=\frac{1}{m n} S_{m n}^{2}=\frac{0,0018}{64}=0,000028125, \\
S_{b}=0,0053
\end{gathered}
$$

Далі для кожного коефіцієнта рівняння (8) визначаємо розрахункове значення критерію Стьюдента як відношення абсолютного значення коефіцієнта регресії до середнього квадратичного відхилення помилки його визначення:

$$
t_{i}=\frac{\left|b_{i}\right|}{S_{b_{i}}} ; t_{0}=796 ; t_{1}=196 ; t_{2}=126 ; t_{3}=143 ;
$$

де індекси критеріїв відповідають індексам коефіцієнтів рівняння регресії (8).

Для знаходження критичного значення $\mathrm{t}_{\mathrm{kp}}$ за таблицею П2 додатка [10] визначимо число ступенів свободи $f^{*}=n(m-1)=56$ й, прийнявши рівень значимості $q=0,05$, знаходимо $t_{\text {кр }}=2$. Коефіцієнти регресії значимі за умови, що $t_{i}>t_{\text {кр }}$, а якщо ні, то ухвалюється гіпотеза про рівність генерального коефіцієнта регресії (тобто генеральної сукупності значень факторів). Порівнюючи розрахункові значення $t_{i}-$ критерію з табличним $t_{\text {кр }}=2$, доходимо висновку про необхідність виключити з рівняння (8) коефіцієнти парної взаємодії факторів $x_{12}, x_{23}$ і потрійної взаємодії $x_{123}$ як статистично незначущі. Необхідність перерахування інших коефіцієнтів відсутня, тому що при ортогональному плануванні ПФЕ всі коефіцієнти незалежні.

3 огляду на викладене, рівняння (8) перепишемо

$$
y=4,22+1,04 x_{1}+0,67 x_{2}+0,75 x_{3},
$$

Перш, ніж проаналізувати отриману регресійну модель цільової функції (1) у вигляді рівняння (12), необхідно перевірити адекватність моделі даним експерименту за допомогою оцінки відхилень значень $\hat{y}$ (табл. 4), обчислених за рівнянням (12), від експериментально встановлених і усереднених за числом паралельних дослідів у точках факторного простору $y$.

Згідно із вказівками [9, с. 121], підставимо у формулу (12) значення (+1) і (-1) відповідно до матриці планування ПФЕ, знайдемо розрахункові значення $\hat{y}$, що занесені вище у табл. 4. Далі 3 метою перевірки адекватності моделі використовуємо критерій Фішера

$$
S_{a}^{2}=\frac{m}{n-k} \sum_{i=1}^{8}\left(\overline{y_{i}}-\hat{y}_{i}\right)^{2}=0,0008,
$$

де $\hat{y}_{i}-$ значення функції відгуку, зумовлене рівнянням (6.17) для кожного досліду, $\kappa=4$ - число членів апроксимуючого полінома у вигляді зазначеного рівняння. Тоді розрахункове значення $F-$ критерію (дисперсійне відношення) становитиме:

$$
F=S_{a}^{2} / S_{m, n}^{2}=0,0008 / 0,0018=0,444 .
$$

Число ступенів свободи становить: $f_{1}=n-k=4 ; \quad f_{2}=n(m-1)=56$.

За таблицею 48 додатка [9] для рівня значимості $q=0,05$ визначаємо критичне значення параметра $F_{k p}=2,56$. Згідно 3 методикою ПФЕ при співвідношенні $F<F_{\kappa p}$ модель признається адекватною реальному процесу. Результат порівняння $F=0,571<F_{k p}=2,56$ дає змогу констатувати адекватність рівняння регресії (12) реальному процесу витікання газу в генераторі тяги залежно від кількості $n$ сопів, діаметрів $d$ отворів їх поперечного перерізу й тиску $p$ у генераторі тяги.

Для оцінки внеску коефіцієнтів регресії в рівняння моделі використовуємо множинний коефіцієнт кореляції, результат розрахунків якого за даними табл. 4 становив:

$$
K=\sqrt{1-\sum_{i=1}^{n}\left(\bar{y}_{i}-\hat{y}_{i}\right)^{2} / \sum_{i=1}^{n}\left(\bar{y}_{i}-\bar{y}\right)^{2}}=0,99998 .
$$

Коефіцієнт кореляції може змінюватися в межах $0 " K^{\prime \prime} 1$, де рівність нижній межі свідчить про відсутність якого-небудь впливу, внесеного коефіцієнтом регресії, i, навпаки, рівність верхній межі вказує на те, що рівняння регресії повністю описує результати експерименту.

Таблиця 5

Розрахунок коефіцієнта кореляції

\begin{tabular}{|c|c|c|c|}
\hline $\begin{array}{c}\text { № } \\
\text { досліду }\end{array}$ & $\bar{y}_{i}=\ln t_{i}$ & $\left(\bar{y}_{i}-\bar{y}\right)$ & $\left(\bar{y}_{i}-\bar{y}\right)^{2}$ \\
\hline 1 & 6,68 & 2,46 & 6,05 \\
2 & 4,59 & 0,37 & 0,14 \\
3 & 5,34 & 1,12 & 1,25 \\
4 & 3,26 & $-0,96$ & 0,92 \\
5 & 5,19 & 0,97 & 0,94 \\
6 & 3,09 & $-1,13$ & 1,28 \\
7 & 3,83 & $-0,39$ & 0,15 \\
8 & 1,76 & $-2,46$ & 6,05 \\
\hline & & \multicolumn{2}{|c|}{$\sum\left(\bar{y}_{i}-\bar{y}\right)^{2}=16,78$} \\
$\mathrm{n}$ & $\bar{y}=4,218$ & \multicolumn{2}{|c|}{$\sum\left(\bar{y}_{i}-\hat{y}\right)^{2}=0,0004$} \\
& & \multicolumn{2}{|c}{} \\
\hline
\end{tabular}


У нашому випадку, 3 урахуванням даних табл. 5, коефіцієнт кореляції становив $K=0,9998$, отже, рівняння регресії (12) практично повністю описує результати експерименту.

Дослідження регресійної моделі функиії відгуку. Рівняння (12) в кодованих змінних встановлює статистичну залежність між параметром оптимізації й факторами, тобто змінними кількості сопів, діаметром їх поперечного перерізу й тиском у них.

Аналізуючи величину й знак кожного коефіцієнта регресії (12), можна одержати достовірну (тому що адекватність моделі перевірена за критерієм Фішера, див. вище) інформацію про вплив факторів на параметр оптимізації та виробити стратегію пошуку екстремуму цільової функції. У рівнянні (12) коефіцієнти при змінних $x_{1}, x_{2}$ позитивні, отже, збільшення кількості сопів у генераторі тяги й тиску в соплах приводить до росту аеродинамічної піднімальної сили генератора тяги. Той самий ефект має місце й при збільшенні діаметра, точніше площі їх поперечного перерізу сопів. Однак домінуючий вплив, судячи зі значення коефіцієнта, виявляє кількість сопів і в меншій мері тиск у них порівняно зі збільшенням внутрішнього діаметра сопів генератора тяги. Інші коефіцієнти при парному $x_{12}, x_{23}$, а також потрійній $x_{123}$ взаємодії факторів були виключені як статистично не значимі згідно із критерієм Стьюдента за формулою (11).

Зазначимо, що вплив ефектів взаємодії проявляється тільки на самих комбінаціях факторів і не поширюється на аналіз впливу кожного фактора окремо. Автономний вплив факторів визначається величиною й знаком коефіцієнтів при них. Отримані дані вказують напрям пошуку оптимуму, але ще не дають змоги визначити оптимальні або, принаймні, квазіоптимальні параметри генератора тяги.

Для знаходження координат екстремуму перевіримо можливість існування останнього в заданій технологічно прийнятими обмеженнями (3) області факторного простору. Із цією метою підставимо кодовані значення змінних (5) у рівняння (12) i, потенціюючи, одержимо вираження цільової функції (1) у натуральному вираженні:

$$
R=e^{5.68}(n)^{0.988}(p)^{0.965}(d)^{0.99},
$$

де $e=2,72-$ постійний коефіцієнт, основа натуральних логарифмів.

Умова існування екстремуму цільової функції (15) в деякій точці факторного простору з координатами $\left(n_{0}, p_{0}, d_{0}\right)$ має вигляд:

$$
\frac{\partial R}{\partial n}\left(n_{0}\right)=\frac{\partial R}{\partial p}\left(p_{0}\right)=\frac{\partial R}{\partial d}\left(d_{0}\right)=0,
$$

У геометричній інтерпретації ця умова має визначати рівність кутів нахилу дотичних до кривої функціональної залежності в однойменних точках $k_{n}\left(n_{0}, R\right)$ и $k_{d}\left(d_{0}, R\right)$ при $p_{i}=p_{0}$. Однак, як видно з графіків рис. 4 , визначені кути не рівні. Отже, умова (16) для значень факторів усередині області варіювання не виконується. У цьому разі завдання оптимізації може вирішуватися аналітично як завдання на умовний екстремум цільової функції за допомогою відшукання екстремальних значень параметра оптимізації на границях факторного простору. Нас цікавить максимально можливе значення сили реактивної тяги $R$ у заданих межах (3) варіювання трьох незалежних факторів: кількості сопів $n$, надлишкового тиску $p$ у них і діаметрів $d$ поперечного перерізу сопів.

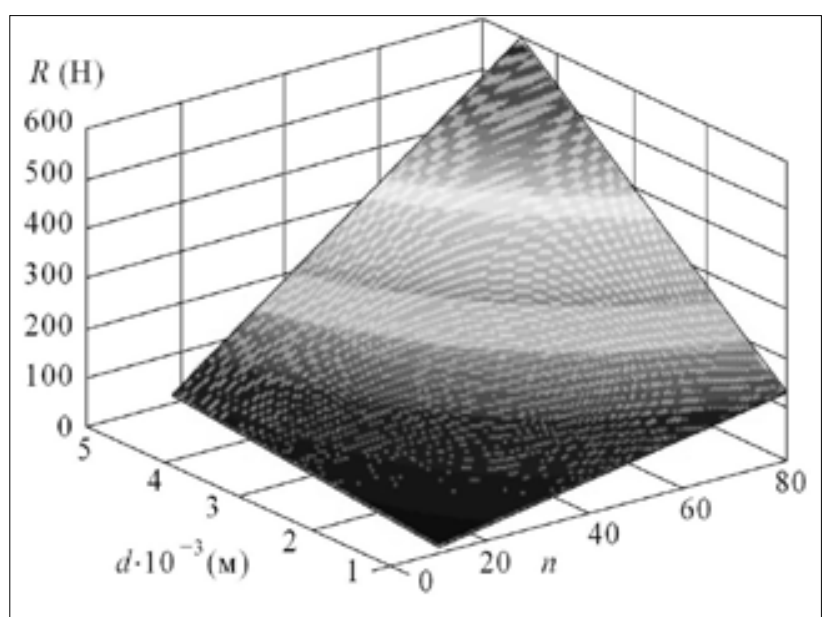

Рис. 4. Залежність сили тяги $R$ від кількості $\boldsymbol{n}$ сопел і діаметрів $\boldsymbol{d}$ отворів при сталому тиску $(p=6$ бар)

Тому знайдемо частинні похідні за кожною незалежною змінною (15):

$$
\begin{aligned}
& \frac{\partial R}{\partial n}=0.988 e^{5.68}(n)^{-0.012}(p)^{0.965}(d)^{0.99} ; \\
& \frac{\partial R}{\partial p}=0.965 e^{5.68}(n)^{0.988}(p)^{-0.035}(d)^{0.99} ; \\
& \frac{\partial R}{\partial d}=0.99 e^{5.68}(n)^{0.988}(p)^{0.965}(d)^{-0.01}
\end{aligned}
$$

3 формул (17) видно, що частинні похідні приймають додатні значення при усіх значеннях змінних, заданих виразами (3). Звідси випливає, що функція $R$ (реактивної тяги) зростає за умови зростання кожної змінної і досягає максимального 
значення на границях факторного простору, тобто при максимальних значеннях змінних:

$$
R_{\max }=e^{5.68}\left(n_{\max }\right)^{0.988}\left(p_{\max }\right)^{0.965}\left(d_{\max }\right)^{0.99},
$$

Таким чином, у результаті експерименту встановлено, що керування силою реактивної тяги $R$ може бути здійснено за залежністю (15) від трьох незалежних факторів: кількості сопів $n$, надлишкового тиску $p$ у них і діаметрів $d$ поперечного перерізу сопів.

Аналіз впливу чисельних характеристик незалежних факторів на параметр оптимізації, тобто силу реактивної тяги, виконаємо на підставі аналітичного вираження (15) у натуральному вимірі. На рис. 5 представлені графіки залежності реактивної сили тяги $R$ від екстремальних значень незалежних факторів: кількості сопів $n_{\min }^{\max }$ та їх діаметрів $d_{\min }^{\max }$ при зміні тиску в соплах у діапазоні експерименту $p=(2 \ldots 8)$ бар. Згідно з матрицею планування ПФЕ, відображеною вище в табл. 2, екстремальні значення факторів становили: кількості сопів $n_{\min }^{\max }=n_{10}^{80}$, a їх діаметрів $d_{\min }^{\max }=d_{1 \cdot 10^{-3}}^{4,5 \cdot 10^{-3}}(\mathrm{M})$.

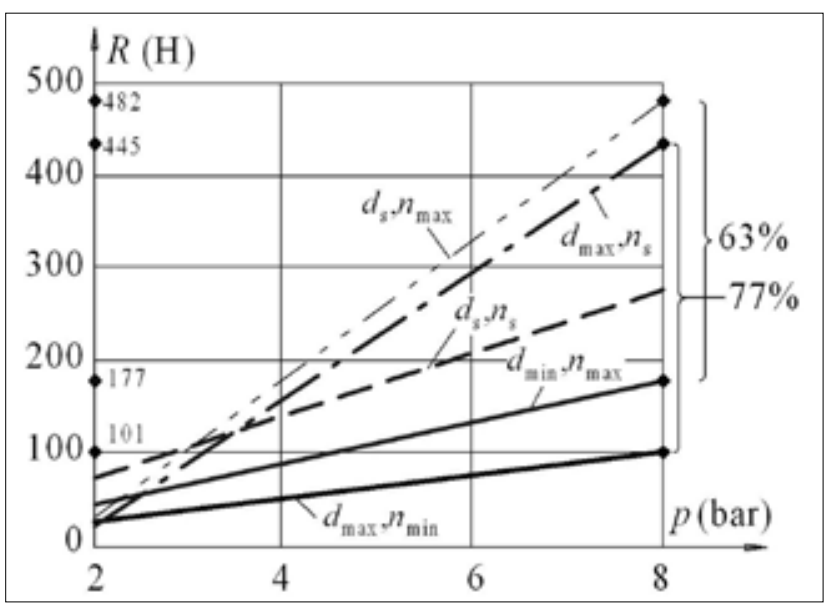

Рис. 5. Залежність сили тяги $R$ від екстремальних значень (min, max) кількості $\boldsymbol{n}$ сопел і діаметрів $d$ отворів у діапазоні тиску $(p=2 . .8$ бар)

На рис. 5 також показані залежності реактивної тяги $R$ від середніх значень факторів, які, згідно 3 табл. 3, як основний рівень варіювання факторів становили: сопів $n_{s}=45$, а їх діаметрів $d_{s}=2,75 \cdot 10^{-3}(\mathrm{M})$. Наведені графіки підтверджують домінуючий вплив коефіцієнта регресії в рівнянні (12) при числі сопів генератора тяги й дають чисельну характеристику зазначеної домінанти.

Так, стає очевидним, що при максимальному тиску $p_{\max }=8$ (бар) у соплах при переході від мінімального значення їх кількості $n_{\min }=10$ до середніх значень $n_{s}=45$ при максимальних діаметрах сопів $d_{\max }=4,5 \cdot 10^{-3}$ (м) приріст сили реактивної тяги становить $77 \%$. У той час як при переході від мінімального діаметра сопів $d_{\min }=1 \cdot 10^{-3}(\mathrm{M})$ до середніх значень діаметрів $d_{s}=2,75 \cdot 10^{-3}(\mathrm{M})$ при максимальному значенні кількості сопів $n_{\max }=80$ зазначений приріст реактивної тяги становить менше, а саме 63\%. Інакше кажучи, відмінність ефективності керування кількістю сопів і ïх діаметрів становить 14\%. Варто помітити, що 3 урахуванням лінійної залежності реактивної тяги від змінних факторів, а саме від кількості сопів, тиску в них і їх діаметрів, зазначена пропорція буде дотримуватися й для інших значень тиску в соплах.

Значення абсолютних похибок у діапазоні від $0,7 \%$ до $5,1 \%$ обчислення реактивної тяги мобільного робота за аналітичною залежністю (15) щодо експериментальних даних, що відображені вище в табл. 3, дають змогу стверджувати доцільність i правомірність керування режимами процесу створення аеродинамічної сили генератора тяги як засобу протидії гравітаційному навантаженню мобільного робота довільної орієнтації в технологічному просторі при виконанні різноманітних виробничих завдань.

Висновки. У результаті проведених експериментальних досліджень шляхом постановки повнофакторного експерименту отримано емпіричний масив даних впливу параметрів генератора пневматичної тяги на аеродинамічну піднімальну силу як засобу протидії гравітаційному навантаженню на мобільного робота.

Дослідження регресійної моделі функції відгуку доводить наявність умовних екстремумів на границях факторного простору зміни параметрів генератора тяги для створення аеродинамічної протидії гравітаційному навантаженню мобільного робота.

Аналіз чисельних характеристик впливу параметрів генератора тяги на величину аеродинамічної піднімальної сили мобільного робота підтверджує домінанту впливу чисельності сопів генератора тяги щодо діаметрів їх поперечного перетину та надлишкового тиску в камері генератора.

В остаточному підсумку проведені експериментальні дослідження надають достатні підстави ствердження доцільності використання аеродинамічної сили для компенсації та протидії гравітаційному навантаженню 3 метою підвищення надійності утримання мобільних роботів у технологічному просторі довільної орієнтації. 


\section{Список літератури:}

1. Manuel F. Silva and J. A. Tenreiro Machado. A Survey of Technologies and Applications for Climbing Robots Locomotion and Adhesion. Climbing and Walking Robots / Behnam Miripour. London, 2010. 25 p.

2. Raju D.D, Jaju S.B. Developments in wall climbing robots: a review. International journal of engineering research and general science. 2014. №. 2. P. 35.

3. Saundersa A., Goldmanb D.I, Fullb R.J. and Buehlera M. The RiSE Climbing Robot: Body and Leg Design. Boston Dynamics, Unmanned Systems Technology VIII. Proc. of SPIE Vol. 6230. 2005. 13 p.

4. Tin Lun Lam, Yangsheng Xu. Tree Climbing Robot: Design, Kinematics and Motion Planning. Springer Heidelberg, New York, 2012. 178 p.

5. Polishchuk M.N., Oliinyk V.V. (2020). Dynamic Model of a Stepping Robot for Arbitrarily Oriented Surfaces. Hu Z., Petoukhov S., Dychka I., He M. (eds) Advances in Computer Science for Engineering and Education II. ICCSEEA 2019. Advances in Intelligent Systems and Computing, vol. 938. Springer Cham.

6. Simon Ruffieux, Auke Ijspeert, Carlo Menon. Modelisation and Simulation of Climbing Robots. Simon Frazer University. 2008. 21 p.

7. Антигравітаційний мобільний робот Поліщука: пат. 120410 Україна: № а201805661. МПК B62D57/024; заяв. 22.05.2018; опубл. 25.11.2019, Бюл. № 22.

8. Полищук М.Н. Теоретическое обоснование функционирования антигравитационного мобильного робота. Вчені записки Таврійського національного університету імені В.I. Вернадського. Технічні науки. 2019. Том 30 (69) № 3. С. 1-9.

9. Пляскин И.И. Оптимизация технических решений в машиностроении. Москва : Машиностроение, 1982. $176 \mathrm{c}$.

10. Барабащук И.Б., Креденцер Б.П. Мирошниченко В.И. Планирование эксперимента в технике. Киев : Техника, 1984. $198 \mathrm{c.}$

11. Шенк Х. Теория инженерного эксперимента. Москва : Изд-во «Мир». 1972. 381 с.

\section{Polishchuk M.M., Tאach M.M. STUDY OF AERODYNAMIC LIFT MODULE FOR A MOBILE ROBOT OF ARBITRARY ORIENTATION}

Mobile robots of vertical movement, known in publications under the name Climber Robot, is a relatively new means of mobile robotics. Such robots are able to perform production tasks on surfaces of arbitrary orientation in the technological space, and are designed to perform various operations in extreme production conditions, including technological disasters, while overcoming the gravitational load. Well-known experimental studies of these robots are mainly devoted to the creation of subsystems for coupling a robot to a moving surface. This is explained by the fact that these subsystems are an integral part of mobile robots of arbitrary orientation in space.

These studies contain the results of experimental testing of a fundamentally new approach to counteract the gravitational load of a mobile robot, namely, the proof of the advisability of equipping the robot with a source of reactive thrust of a non-chemical origin. A pneumatic generator of aerodynamic lift is proposed as such a source. This force partially compensates or completely overcomes the gravitational load, while not allowing the transformation of a mobile robot into an aircraft. In other words, the thrust force should not exceed the adhesion forces of the mobile robot to the displacement surface. In addition, the proposed article contains an experimental solution to the problem of finding the quasi-optimal values of aerodynamic lift depending on the parameters of the jet thrust generator. The methodology and description of the formulation of the full factorial experiment with the variation of independent factors at two extreme levels are presented. The use of aerodynamic lifting force as a means of counteracting the gravitational load helps to increase the reliability of the retention of mobile robots on the displacement surface of arbitrary orientation in the technological space.

Key words: mobile robots, walking machines, robots of vertical movement, climbing robots, aerodynamic force. 